\title{
(-)-Epigallocatechin-3-Gallate Inhibits eNOS Uncoupling and Alleviates High Glucose-Induced Dysfunction and Apoptosis of Human Umbilical Vein Endothelial Cells by PI3K/AKT/eNOS Pathway [Corrigendum]
}

\author{
Zhang Z, Zhang D. Diabetes Metab Syndr Obes. \\ 2020;13:2495-2504.
}

It has come to the authors attention that the concentration of the used compound EGCG in Figures 1-5 is given in $\mu \mathrm{m}$ (micrometer) where it should be $\mu \mathrm{M}$ (micromolar). The figure legends are correct with $\mu \mathrm{M}$.

The authors apologize for this error in the figures.

\section{Publish your work in this journal}

Diabetes, Metabolic Syndrome and Obesity: Targets and Therapy is an international, peer-reviewed open-access journal committed to the rapid publication of the latest laboratory and clinical findings in the fields of diabetes, metabolic syndrome and obesity research. Original research, review, case reports, hypothesis formation, expert opinion and commentaries are all considered for publication. The manuscript management system is completely online and includes a very quick and fair peer-review system, which is all easy to use. Visit http://www.dovepress.com/testimonials.php to read real quotes from published authors. 